\title{
NOTES ON FEMININITY, OR THE BIG STORY OF A LITTLE DRESS
}

\section{STOYAN ASENOV}

DSc in Philosophy, Professor.

Sofia University “St. Kliment of Ohrid”, Faculty of Philosophy. 1000 Sofia, Bulgaria.

E-mail: asenov@phls.uni-sofia.bg

In 1926 Coco Chanel designed the little black dress and this marked the beginning of the remarkable longevity of this garment in the world of fashion. This longevity embodies the paradox of being always in fashion in a world of transience. This paradox allows us to see in the little black dress a unique story unraveling between the body and the dress, which represents the woman beyond ephemeral fashion and gives femininity a unique status. The little black dress is a phenomenon which affords us the opportunity to reveal some fundamental characteristics of the modern ways of constituting the body and femininity. An important question to answer here is how philosophy can address the understanding of this particular phenomenon. I think that even though the reconstruction of this phenomenon within the confines of the specific cultural and historical context could yield important considerations, this approach is more likely to hinder understanding because it fails to highlight the uniqueness and integrity of the subject being studied. Therefore, this text employs a different approach: understanding is only possible through a phenomenological interpretation of the "interplay" between the body, the colour black and the smallness of the dress - that is, through a phenomenological interpretation of the relationship that exists between the black clothing and the body and the "work of the small". The main premise is that this "interplay" temporalises the body thus rendering the little black dress a phenomenon of time above all. The body leaves the physical mode of existence whereby natural femininity becomes historical and biographical. Within this context the mystique and allure of femininity are not so much exuded by the physicality of the body as are connoted by the body's representation as a concealed story and a hidden biography. In this way the woman is enabled into a new form of existence - that of a story; however, this is not a story of the natural woman, but the story of a biographically individuated femininity. This gives new dimensions to the erotic inasmuch as it goes beyond the erotic that stems from the immediate sensation and image and becomes the erotic that stems from the imagination. Key words: Body, femininity, temporalization, freedom, fashion, the erotic, colour, garment, imagination.

(C) STOYAN ASENOV, 2017 


\section{ЗАМЕТКИ О ЖЕНСТВЕННОСТИ, ИЛИ БОЛЬШАЯ ИСТОРИЯ МАЛЕНЬКОГО ПЛАТЬЯ}

\section{СТОЯН АСЕНОВ}

Доктор философских наук, профессор.

Софийский университет Св. Климента Охридского, философский факультет.

1000 София, Болгария.

E-mail: asenov@phls.uni-sofia.bg

В 1926 г. Коко Шанель создает маленькое черное платье и этим событием отмечено начало удивительного долголетия этой одежды в мире моды. Такое долголетие парадоксально: что-то остается всегда модным в мире изменчивости. Этот парадокс позволяет нам взглянуть на маленькое черное платье как уникальную историю отношений между телом и одеждой, которая репрезентирует женщину вне эфемерности модного и придает женственности специфический статус. Феномен маленького черного платья позволяет нам раскрыть существенные черты современного конституирования тела и женственности. Важный вопрос, на который мы пытаемся здесь ответить, заключается в том, как философия может подойти к осмыслению этого феномена. Реконструкция конкретного культурно-исторического контекста, несмотря на свою значимость, скорее затруднила бы понимание этого феномена, так как ускользнет уникальность и целостность предмета исследования. Данная статья предлагает иной подход: понимание возможно, если феноменологически раскрыть «игру» между телом, черным цветом и маленьким [платьем], то есть отношение между черной одеждой, телом, и «работой» малого. Основная предпосылка предлагаемого автором анализа заключается в том, что эта «игра» темпорализует тело, и поэтому маленькое черное платье является, прежде всего, временным феноменом. Тело выходит за пределы физического способа существования, и природная женственность становится исторической и биографической. Таким образом, тайна и очарование женственности возникают не столько вследствие физических особенностей тела, a, скорее, в репрезентации его как утаенной истории, как скрытой биографии. Таким образом, женщина предстает как рассказ, но это не рассказ о «природной» женщине, а о биографическо-индивидуализированной женственности. Тем самым открываются новые измерения эротического, поскольку оно выходит за пределы эротики непосредственного ощущения и образа и становится эротикой воображения.

Ключевые слова: Тело, женственность, темпорализация, свобода, мода, эротическое, цвет, одежда, воображение.

It was in 1926 that Gabrielle Chanel, better known as Coco Chanel, created her little black dress. Since then, for almost one century, the dress has been not only fashionable, but also something of a mandatory piece in a woman's wardrobe. Without doubt, this is remarkable longevity in the fashion world, especially considering that, as Oscar Wilde said, fashion is a form of ugliness so intolerable that we have to alter it every six months. The remarkable longevity of the black dress makes its presence in the transitory world of fashion somewhat of a paradox. 
By virtue of the very fact that it is always in fashion, the dress appears to go beyond what is fashionable, to become un-fashionable, and its existence to become that of an oxymoron: being always in fashion. By removing the fundamental disquietude of fashion - the concern about whether or not one is fashionable - the dress instils a peculiar kind of security in a place that is in a constant state of flux. Not only does the little black dress transcend time and is the apparel of choice for both morning and evening, yesterday and today, but it also becomes the topic of conversation at various social affairs as if it were a celebrity. In other words, the little black dress is not simply a moniker, but a name that is the topic of conversation and is the subject of social chatter and scientific discourse; women can readily recall the black dress's name, everyone can recognise its visage, and thus it enjoys a presence in the public eye as if it were a social persona of its own.

By eschewing the fanfair of fashion's seasonality, the little black dress relates to body and time in a much deeper way which fuels the undying passion of their reciprocity. The persisting urge to don it is perhaps due not only to the desire to evoke the submissiveness of a charmed gaze, but also by the need to summon the sense of an enduring, caring protection of femininity that the dress seems to provide.

Clearly, the little black dress is a one-of-a-kind phenomenon in the world of fashion - a peculiar piece of tiny apparel capable of having a grand history.

Perhaps the secret of the little black dress can be found in the fact that even at first glance it appears as a confluence of multitudes of meanings, as well as of diverse currents and trends, both within and outside of the history of fashion.

It is well known that the little black dress was not only a part of, but also one of the most prominent examples of the fashion trend in the early $20^{\text {th }}$ century especially after World War I - regarding the simplification of garments. Coco Chanel was a zealous champion of that trend. Pure, even austere lines, the avoidance of luxurious fabrics and designs, as well as a certain modesty of the cut were all defining features of the new tastes in fashion. According to Gilles Lipovetsky, it was then that women's fashion stepped into the era of "democratic externality". He writes:

Chanel and Patou rejected ostentatious luxury, the ornaments on dresses, trinkets. Women shall wear straight short dresses, small and simple bell-like hats. Chanel succeeded in dressing women from the elite in jersey suits or in black, grey or beige pullovers. It started to be seen as chic not to look rich. The aesthetic established for $19^{\text {th }}$ century men's clothing by Beau Brummell spread to and took over women's clothing - glaring ornateness started to yield to the democratic aesthetic of purity, austerity and comfort. (Lipovetskii, 2012, 84) 
In the little black dress's simplicity one can sense the tendency in fashion to make garments more commonplace, to welcome the ingress of the street and its mainstream taste. US fashion magazine, Vogue, called the little black dress "Chanel's Ford", thus underscoring the dress's functionality and practicality, as well as its potential for mass production. The dress thus became inscribed in the aesthetics of functionality, depriving itself to a large degree of its uniqueness insofar as being reproducible.

All of this constitutes a scandal in the circles of haute couture. Journalist Janet Flanner argued that Chanel introduced "the style of poverty" into fashion, while early $20^{\text {th }}$ century fashion guru Paul Poiret ironically remarked that her dress turned women into small malnourished telegraph operators. In a twist of fate, the purveyor of fashion as "poverty de luxe" (this is how Poiret defined Chanel) became one of the richest women out there, while, Poiret, the supporter of rich, luxurious fabrics, died in extreme poverty.

At the same time, this simplification of clothing became a criterion for true elegance, which could be sensed in the immaculate cut, the light fabrics, and the unobtrusiveness of the dress's presence.

The little black dress embodies the style of the street, of the everyday, of mainstream taste, and of mass reproducibility. But, at the same time, it is an extremely personal dress, first and foremost, with respect to the body. It is well known that Chanel did not create garments that she would not or could not wear herself. Her own body - slender, almost emaciated, not rounded at all - served as her mannequin and was a model upon which to build her designs. The little black dress is especially telling in this respect. It is as if cut for Chanel's own body - it bears its unique stamp, and that is how the designer created a new idea of female beauty and the bodily attributes of femininity.

Second, the little black dress reflects its own past. The little black dress undoubtedly bears something of the design of monastic garments and Chanel's own uniform from her sojourn in the Aubazine monastery where she grew up. The dress inherited not only something from the aesthetics of a nun's garb, but also bore the expression of a sorrowful childhood - a visualized psychoanalysis. In this element of asceticism, one can also sense the influence of wartime years when all exuberance was inappropriate.

One version of the origin of the little black dress was put forth by American journalist Elsa Maxwell, whom Henry Gidel classified as "a dangerous gossiper"; 
according to this version, "Coco swore on the still warm dead body of Arthur Capel ${ }^{1}$ that she would make all women on Earth walk in mourning garb. That is why she released the little black dresses in the years immediately following the accident" (Gidel, 2008, 156). Regardless of whether or not the story is true, it remains entirely plausible, especially given Chanel's personality. Chanel put a lot of herself into every piece she created, and so it would come as no surprise if some personal story was inscribed in the little black dress's origin. In the dress we can detect something personal and intimate: a personal pain and the power of grief which give the garment a certain element of mutuality through the universality of sorrow and the melancholy of love.

This reveals the little black dress as an object that is intimate to its very core and is an embodiment of personal experience: one's own body, the biography of a sad childhood, and the pain of a dramatic experience.

It is in this way that Chanel connected the mainstream with the unique, the deeply intimate with the universally reproducible. It is in this way that she responded to mainstream taste while at the same time turning the personal into the norm.

Notwithstanding, the little black dress is an emancipatory gesture in the world of fashion. Thus, it becomes an embodiment of the characteristic attitudes of its time and makes its own contribution towards shaping the spirit of the times. Chanel saw freedom as her mission in haute couture - freeing the body from heavy, ornate clothes, while opening up space for movement. She was fond of saying that clothes are for women who move. This fluid mobility expressed by the dress and the body became part of women's new image in the post-war era: women who like to have fun, to play sports, to move freely, and were inclined to breach the rules of propriety. All of this became the foundation for a new ideal of femininity which required a new visual representation. The freedom of body and movement manifested through fashion became part of an emancipatory social presence. This mobility, drawn with a fine and supple contour, combined with the austerity of the colour black, presents a woman in full possession of herself - a woman who not only feels free, but who is also conscious of her own worth. In this way, the little black dress couples freedom with a certain resoluteness of presence, even with a certain businesslike comportment. Thus, freedom in this context posits a distance and produces an effect of restraint.

1 Arthur Capel - Coco's lover, who helped her career and perished in a car crash. 
Moving in the modest, ascetic, even puritan lines of the little black dress, freedom in a peculiar way transcends these determinations. Women do not come to a standstill within these lines; on the contrary, the simplicity of the dress reveals the audacity of the naked body which does not exclude a certain frivolity in spite of the businesslike austerity of the dress. Asceticism is present, but in appearance only. The little black dress is a monastic garment secularised to the extreme.

The little black dress unites grave earnestness with the joy and play of freedom. It professes a businesslike demeanor - one without absolute boundaries - as a claim for novel and different participation in the world.

The antinomic meanings which the dress conflates transform freedom into a challenge, as well as into a certain je ne sais quoi that demands respect. Thus, the dress constitutes a new, distinctive space of the erotic and of sexuality as it dares to introduce a certain ambiguity into the distinctly outlined gender boundaries. The erotic impulse is both encouraged and stifled by a sense of ambiguity which is hinted at by the subtle androgyny of the dress over which lurks the shadow of the 19 th century man with his austere black suit. Undoubtedly, this new femininity contains within itself the silhouette of the man, not as a conqueror, but rather as a captive who has been carefully situated there and whose movements have been mastered and incorporated into the woman's body. The man is taken aback because, peering into that silhouette, he recognises his own contours. In the little black dress the woman does not give herself up to the man, but rather dominates over him. At the same time, she holds him captive on her own terms - the man is not only ravished, but also nurtured; he experiences his existence in a "prenascent" way.

Speaking of the dress's silhouette, we should mention the connection with modern art, especially cubism, elements of which can be observed in the pure, geometric forms of the little black dress. It is a known fact that some of the fashion circles at the time existed in close relationship to avant-garde art, which included participation in joint projects. The famous fashion designer of that time, Elsa Schiaparelli, worked together with Salvador Dali, while Chanel herself partnered with Pablo Picasso in the theater. But while the garment bears masculine features, it does not confine women within its contours. In the geometric shape of the little black dress we can sense a will different from the one expressed in the man's black suit - a will that softens the dress's lines and gives them a new dimension. 
Why is it that a piece of clothing that was so topical in its expression of the trends and the spirit of its time, a garment that was the manifestation of so much cultural and historical specificity to the degree of becoming one of the prominent cultural artefacts of its era, has become a phenomenon that has been able to outlive the context of its time; especially considering that it was exactly this very context that engendered its very existence in the first place at precisely that point in time? From what we enumerated above, we can see that the little black dress, with all the historical specificity it embodies, is firmly situated in the "now" of its time and in the "now" of its nascency. The meanings concentrated in the little black dress are also factors that led to its emergence in the first place and that historically justify its existence. But this can hardly explain how the dress, a part of the new and scandalous of its time, turned into a constant presence, into a part of the everyday in the times to come.

It is clear that the little black dress creates a unique kind of story between the body and clothing which represents the woman beyond the transitoriness of fashion, and in a peculiar way leads her through time, making her both present and relevant. With its timelessness, the dress is not only a phenomenon of fashion - it also gives a peculiar status to women and femininity. It is this multiformity that holds the answers, as it is in this multiformity that trends and traditions intertwine in a way that strips them of their sole authority and power to dictate the rules. Could this be a way for the little black dress to bring a simpler, more frivolous perception of life; could the dress be an expression of a certain facile lightness in that by borrowing from everything it can relate to everything, it can constellate various dimensions of life, it can carry and express them, and it can flummox with its various meanings? By taking on particular characteristics it becomes relatable, yet by not taking on the whole it remains unfettered. It is possible that these words contain some truth but there is also something bewildering, something that resists the eye. For, if we try to "see" the dress now, it will seem more like a multicolored collage, and as similar as the various features it displays may be, they could hardly be blended together to create a single "face". This resistance of the eye arises from an intuitive feeling which comes from our spontaneous, unreflected experiences, which teach us that the little black dress is far from being a superficial pastiche phenomenon - on the contrary, it has its own eidetic character outside of the aforementioned multifacetedness and its freedom and lightness mean anything but levity and superficiality.

In addition, the manifold of meanings that the dress contains within itself analytically disjoint it and turn it into something literally torn apart by oppositions. 
Clearly, the approach that I have been using so far brings about methodological challenges and hinders understanding. In the dress we can observe the reflections of the external, but it is hard to construct the dress's uniqueness out of them. Each of these pairs of oppositions is like a pair of hands pulling at the dress in different directions, and, as a result, we lose track of the completeness, simplicity and resoluteness of its existence. These opposing determinations sit much like different spots of colour on the garment; in their multitude they are irreconcilable - the dress now appears as a patchwork. Therefore, by lingering on this diversity we have lost the little black dress's colour (assuming black is a colour) and we have lost the integrity of its tonality. Distracted by this diversity, our eye has forgotten about the blackness in which nothing can be discerned. The little black dress justifies all of the aforementioned directions of analysis. However, it is something whole and complete and is therefore a totality beyond its parts, whereas the parts on their own have meaning only with respect to that whole.

That is why we have to do something simpler. We have to entrust ourselves to the immediacy of experience starting from the immediacy of the gaze: a gaze that is not so much "cultural", but rather one grasping an original given. Of course, the garment isn't in itself - it is always garment-and-body and discloses itself in the tension between the two. In this respect, the phenomenological method is indisputably more advantageous in that it beckons us to consider the things themselves and it is most relevant in the unveiling of the images of the body, the meaning of the phenomena that arise out of the interplay between the body and the garment. Furthermore, the phenomenological method allows us to restore the primordial oneness and unity of the body and the dress, and it enables the woman in the small dress to appear before us anew.

That is why one has to remain alone with the woman wearing the little black dress and to let oneself be charmed by the immediacy of her presence.

It is evident that it was the immediate gaze that gave the garment its name: the little black dress. The body exists in a peculiar relationship with the colour black in its abbreviated version: a specific expression of the body through the shortness and the blackness of the dress. Naturally, the colour, rather than the form, becomes the focus of attention as it does not conflict with the details: the little black dress follows the natural lines of the body and lets the blackness gently envelope the body, and 
at the same time, curtail it. Of course, the body clad in black garb has its own long history. This is the story of the encounter with the colour black and with blackness an encounter imbued with drama. I will add some further reflections on this point.

First, black is absolute totality and indeterminateness. It absorbs all determinateness and engulfs all images so as to exist by itself and within itself. As such, black is always a limit to Being and it, therefore, ravishes and transcends existence; it appears within Being as negation. Therefore, black always carries a charge of otherworldliness, which, by the power of its negativity, towers over all things existing, strips them of what they are and erases them from the chronotope of their presence only to engulf them into the vortex of its own indeterminateness. The frock can wield the deadly force contained in the colour black to render negation or self-denial (a denial of one's own body, of one's own self, and of the world), to create death or salvation - that is, the black faceless warrior of darkness or the monk who has withdrawn into the realm of the transcendental. This is what the ravaging power of black can discharge, and this is why the body is kept concealed and invisible. By being negated in this way, the body loses any meaning of its own and becomes solely a vehicle for the colour black and a means of its incarnation and visible expression. The body does not explicate itself through the colour black, but becomes the visible image of the darkness and of the transcendent in its presence and action in the world. This is why the black dress always has a mystical quality to it. In other words, black in this context is able to deflesh that which is immanently corporeal through transforming the very body into colour and through converting its vitality into the life and work of the colour black. This vampirical quality, so to speak, of blackness, has the power to transform the body into an incarnation of itself and absorb the body's energies as its own, but in doing so it does not weaken the body - nay, by depriving the body of its own self, the blackness erases the body as such and it continues to exist solely as an expression and a force of blackness.

By being obliterated by its clothing, the body becomes a vehicle for the incarnation of black. However, if flesh is not a given, but something which is effectuated by external forces, then the body does not really exist under (inside) the black dress, but is rather the sheer volume of blackness which has usurped the body's extension and locus and operates through the body's abilities. Blackness is the body's matter - its material and inner element. However, this is not a mechanical blackening of the body's atoms, but is, rather, a process wherein the atoms of blackness reconfigure themselves into bodily molecules, overcome the body, and evacuate it out of its own frame so as to create blackness in flesh. 
Thus, the body becomes a vehicle for the physical manifestation of blackness in the world, a specific anthropologization of darkness. In the process of its anthropologization and morphing into black flesh, blackness is able to ontologically transform the human being by absorbing the body into its own matter. The body is left with neither a locus, nor visibility of its own; it is devoid of its immanent humanness and this state can be translated twofold: in one instance the negative force of the colour black can turn this state into self-denial and an impulse for the transcendental; the other route is to turn this state into negation which manifests the reign of punitive power or simply the fact of death and its ensuing grief. All of this is inevitably reflected in the way the body is visually perceived. Representing the monk it appears dissipated, and representing the warrior of darkness, the body looms as a menacing visage of something other than itself. When black is anthropologized and incarnated into flesh, it becomes a formidable presence - the ampleness of the long black dress gives ampleness to the body and enhances its visibility in two different ways: in the first instance black extracts the body from the world and materialises its absence, in the second - it reinstitutes it back into the world after it has been obliterated.

The absoluteness and indeterminacy of black allows for a meonic ${ }^{2}$ charge to appear within black itself which turns it into a field of possibilities (Asenov, 2014, 164-174). These traits give a liminal metaphysical framework for apprehending the colour black. Black appears before us as a world within the world.

However, our experience suggests that black can also be dispersed throughout the world as fragments of it coexist with the colours of life and, very often, instead of making itself explicit, it articulates in an inimitable way life itself and plays an ambiguous game with the things of the world. Without losing itself, it adorns Being, giving it a new dimension. Our discussion here of the relationship between black clothing and the body is an extreme example of the power of garment and colour. However, this power can be used with measure: by hiding a part of the body and by delineating it the garment and the colour can make everything else more prominent. A good example of this is the long black frock which leaves only the head showing. This configuration is reminiscent of the nobility and still grandeur of a monument as it turns the body into a pedestal for the head. By leaving the head outlying and exposing its expression, the edges of the black dress in this case seem to guillotine the

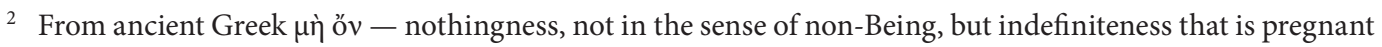
with possibilities. 
body, separating it from its internal invisibility, thus containing and minimalising the body's own physical presence. This explains why this kind of clothing is an inseparable part of many ascetic practices. The black garment has a way of making one visible through the expressiveness of their head. The head is a singular part of the body in that it is at the head that the body seems to end, in a sense, and seems to become its alter ego - it becomes spiritualised. The head, in a way, defleshes the body because in the head spirit overwhelms matter, as it were, and it is in the head that a human being becomes a person. The long black dress has a way of elongating the human in the direction of the face and the spirit and thus concentrates its wearer in the upper part of the body - the human being becomes but spirituality which has risen up from darkness.

However, the interplay between black, the black dress and the body is much more evident in some present-day versions of the formal female dress where the dress maintains its length but loses its wholeness and integrity. The usual design of the long black dress allows for one or more deep slits that run high up the leg; in addition, the dress leaves uncovered various other parts of the body - most often the back, the shoulders, part of the chest and, in some cases, the belly or the hips. In this way, the black colour of the dress delineates parts of the body, frames them and specifically exhibits them. The focus here is not on the wholeness of the body; on the contrary, the body is almost dismantled into framed parts and becomes a sequence of images. The black colour of the dress delineates borders along the body thus exposing the body through its parts - their facticity represents the body and it acquires the meanings conveyed by this facticity. The head and the face can also be framed but in doing so they lose their unconditional meaning. This relationship between the body and the dress combines austerity (represented in the length of the dress and the covered parts of the body) with the sensuality of the exposed body parts which create the feeling of nakedness. This is why movement becomes very important here, because movement repeatedly reveals and covers the body, which, in turn, seduces with the immediate sensuality of nakedness and with the mixed messages. Therefore, the intimate cooperation between the body, the dress and the undeniable eroticism which the black colour of the dress underscores are most visible in the long slit which acts as a movable frame and a curtain which rises and falls. In this one-person show the woman is never at peace; her persence reveals movement as the dynamic tension between dressing and undressing.

In focusing on the various relationships between the black gown and the body our purpose is not so much to trace their long history together as it is to demonstrate 
the complexity and diversity of all the typological possibilities of interaction that can be extrapolated from the relationship between the two. Undoubtedly, these interactions are charged with symbolism and meaning, with a specific way of constituting the human, as well as with different manifestations of his/her presence, and they represent a very immediate form of communication with him/her. In its essence, black is domineering - it is a "subject", and does not easily lend itself to being transformed into an instrument; therefore, its utilisation by man through clothing has always been a strong statement: a clearly communicated message which is not about the peripheral aspects of life, but is a comment on life's essence and its radical expression. This is why black has the power to completely transcend the human being, to efface him. The burqa is the most extreme example of the anonymity that black clothing affords its wearer as it eschews the possibility for any publicness of the individual; it is more of a domicile than a garment and allows women to feel at home even when they are outside, thus granting them the safety and security enjoyed by domestic creatures. In contrast, the short dress is the enigma of the private almost completely revealed; it is brought down to its last remains, and is but a rudimentary element which demonstratively points to the direction of its disappearance.

So, let us say again that black co-exists with life and is able to articulate it in an inimitable way and to reveal the multiplicity of its dimensions.

The little black dress is undoubtedly an example of this.

The immediate gaze gave the garment its name. In addition to being black, it is also little, i.e. in it we can detect the distinctly peculiar "work of the small".

The small minimises the negative force of the colour black and emphasises its meonic charge, its potency, its hidden vitality. Minimising itself, black cedes part of its power to the body, giving it space, freedom and visibility, while keeping its completeness and integrity. In this way, the original immediacy of the body its white nakedness ${ }^{3}-$ attains spatial visibility. In this classic opposition of white

\footnotetext{
Due to its total achromaticity, the colour black - just like the colour white - is always in contrast with any skin tone it is set against. Naturally, this contrast is most defined against white skin tones and, therefore, it has the strongest connotations in this context. When the colour black is combined with a skin tone that is darker or otherwise different than white, these connotations are still valid but are open to other possible interpretations such as a possible focus on the demarcation between flesh and clothes and the degree of attenuation of that boundary. In this context another element is added to the body-clothing relationship, as well as to the erotic and freedom.
} 
nakedness and blackness, we can discover a repeating, archetypal opposition. This is the opposition between light and darkness, the pulsations of day and night the day that makes appear the white flesh of the world, and the night that hides it. But nakedness and whiteness do not become dominant: black does not paralyze but emphasises; it does not expose, but rather delicately hints; it seduces without imposing. In this way, black reveals and conceals just enough to create mystery and depth without leaving the body in the realm of the invisible or annihilating it. A balance emerges between public openness and intimacy. By covering the entire body $a$ black dress creates an inner space for it where the body can exist in secret invisibility; the little black dress, however, does not put the body on display during the act of undressing (at times when it is being used, so to speak) but is rather, in and of itself, an externally explicit secret which black both alludes to and conceals.

Let us return to the colour black and its manifest presence. Smallness does not destroy the substantiality of black, which is to feed on Being, to annihilate, and to be completely indiscernible. But at the same time, by minimizing black, the little black dress appears to limit its negative power. As a rule, in blackness matter becomes more dense, solid and concealed; in this case, however, black does not conceal the body, but rather makes a shelter for it. Let us not forget that in this example black isn't in itself, but is animated by the body. By virtue of its smallness, the blackness of the little black dress allows itself to be vitalized by the movements of the body, as well as by its whiteness and nakedness. Thus, black becomes rich with possibilities, therefore, anything can be expected from it - it can bring hope where there is a lack of satisfaction and it can become the source of all fear. Black is the internal dimension of an inferred freedom, an implicit power. We could imagine the body as the internal shining essence of blackness and that it is the bright-white core that blackness envelopes. Then, we would be attracted by an intimated but undisclosed purity, by some internal light. But this opposition is too trivial to be true and, most of all, it contradicts experience. Rather, blackness is, in a way, the reverse side of whiteness, the paradoxical form of its manifestation, but it is whiteness that is sufficiently and clearly expressed through the resoluteness of the blackness yet lacking any concreteness; it is just a shadow of whiteness, leaving it absolutely indeterminate and mysterious. Thus, black is not the mask of some white essence nor is it a surface unrelated to the body - it is rather the exteriorisation of the intimate which reveals itself in the indestructible substantiality of black. Whiteness itself acquires an otherworldliness of its own by virtue of which it relinquishes the 
simplicity and resoluteness of its innocence; it acquires a particular depth which both engenders and engulfs it.

In this way, the little black dress reveals the hidden beneath it just enough to channel desire. It carries black's resoluteness, but minimises fear without eliminating it; it makes hope better defined, but without reducing it to raw facticity. The erotic impulse is both triggered and stifled by the apprehension of danger and by the intuition of a possible dark temper which the mix of freedom and black confers.

The shimmering whiteness of the body does not emerge from a source of innocence; it charms with the vagueness of a dark past.

What is it about a woman wearing a little black dress that is so enticing? She is a dangerous combination of innocence with a dark past. The little black dress overlays innocence with a mysterious past, an inscrutable history. In this way, whiteness and the innocence of nakedness acquire a depth through which the little black dress delivers them from their dull uniformity and imbues them with fear and risk; however, this is not the ethical fear of innocence denouncing itself and becoming a thing of the past.

The woman in the little black dress emerges out of a story. Thus, the little black dress temporalises the woman's body, gives it a certain temporal depth, and a biography.

In this way, the little black dress attracts and charms, not so much and not only by the immediate, unaffected presence of the natural body, but rather by virtue of representing it as a bodily experience, as a concealed story, and as a hidden biography. The woman in the little black dress is a hint - she is not clearly and distinctly articulated; instead, she invokes an eerie past, a vague image, and a story perhaps true but untold, which welcomes and satisfies our desires, and which excites the imagination and connects longing to the romance of another life.

An erotic sensuality is imparted not only through the immediately sensual nature of the body and the dress, but also by the temporal depth that makes a given sensual moment the end or beginning of a story. Thus, the woman in the little black dress is always beyond the present moment: she resides in all moments of the past. She is the eternal woman who rules over time, turning it into her own personal story. She is the woman whose steps can be overheard in the lines of the Bulgarian poet Boris Hristov: "I have arrived... I am Maria - the woman of all men, even of the dead...." 
Firmly ensconced in time, the woman in the little black dress begins to sound like a legend - a legend in which the very past is a sensual, erotic unfolding of time pattered into existence by the steps of the woman in the little black dress.

By temporalising the body, the little black dress articulates the past as a rumour. In the rumour, this biography does not claim any authenticity, it simply exists and is rather given as a vague approximation of truth and therein lies its appeal. The nature of this story echoes the nature of the night. Both in blackness and in rumour the woman is indeterminate and, thus, desire resembles the longing to go out into the night where all things are and where all things happen.

The woman concealed in the rumour conveys a desire for disclosure. The woman in the little black dress is always the beginning of a narrative, of a story. More than anything she stimulates the imagination; she inspires the telling of stories, the sharing of gossip, and the spreading of rumours. By historicising the body and giving it an obscure biography, the little black dress involves us in the narrative, as well as in a life which, as imagined and overheard it may be, can still be communicated through storytelling.

The woman in the rumour transforms the desire to tell into a desire to share and to invite the listener into the story. Thus, the unbridled desire becomes the desire to listen; the erotic becomes a penetration into a past and the incorporation into a story, perhaps through the communion of bodies. Therefore, love is revealed as a form of integration and a way to hearken to a story which resounds beyond the spoken word or even precedes any words. José Ortega y Gasset said that love is a phenomenon of attention - here we can say that it is a phenomenon of attentive listening. The little black dress creates an expectation beyond the body's mere physical nature, insofar as the body itself is already beyond itself, in a history that conquers us.

From the preceding text it is clear that the erotic here is not so much about a tangible sensation or image, but is rather an erotic of the imagination. Although it triggers the erotic, the image itself is eroticised by the imagination (the imagined), and by the depth of its own inferred history. But this imagination is no mere fancy, for it is founded in the rumour, which is not external gossip, but is the story that the woman in the little black dress whispers about herself. In this way, she references the observer beyond herself, beyond her concrete image; this imagined 
history, this obscure biography becomes the actual substantial vitality filling up and making possible each specific meaning and image, while remaining at the same time transcendent and indeterminate. In this way, the image becomes an event; it becomes dynamic and opens up the possibility for the woman in the little black dress to infinitely seduce, thus endowing the imagination with boundlessness.

In this seduction we are summoned to boldness, but are also held back and conquered. Summoning and restraining create a fine form of domination, a readiness to serve and a feeling of doom in which we can sense the overtones of a desired sweet death.

This cannot but evoke a sense of alarm because we are facing someone superior. Overhearing the rumour we realise that we are outside the story and that we are experiencing a certain deficiency, namely, that we have not been tamed by the story hinted at in the rumour; this deficiency is but a historical and biographical inexperience and ineptitude. We are always ignorant about the woman in the rumour. Whatever our actions, the woman in the little black dress leaves us outside her story and puts us in a strange position of historical homelessness, in an uncivilised barbaric state. Perhaps that is why stories about women are always part of men's conversations - it is the way that men can enter into history. This is the story of a man and a woman, the story of love, and of sharing a mutual experience in all things eternal - in fact, this is the very well known story of Diotima and the young Socrates.

The multiplicity of meanings of the little black dress discussed so far must have some foundation, some substance to them - and that is historicity. But at the same time this historicity is, in fact, a desubstantialisation, an expression of an original metaphysical mobility which was felt in the shift from the physical to the historical. However, this whispered story does not refer to only the past. The mastery of the "now", the austerity of presence, turn historicity into "a right to history", therefore, relating it to the future. Thus, the woman becomes open to her own history - this history becomes a possibility. She becomes situated and lives in the foreboding space of her own story, in the right to invent and to tell it. The right to a personal biography constitutes a distinct biographical kind of femininity which individuates, creating the feeling of uniqueness. This is not the universal history of some natural woman; therefore, expectation here is based on the mobility of this publicly announced historicity rather than on the staticity of a nature. The woman is confident (the power conferred by black) yet longing and fearful; she is both running away and creating herself (like Chanel, herself, who invented her own biography). 
The little black dress shows us the woman as both reality and fiction, dream and presentiment. By being whispered, the history of the woman combines many stories which make up the fabric of femininity - we never know which story we will come across. The woman turns into a story that has already happened, but is at the same time always beginning: the little black dress shows her as a crossroads of stories, of a new mobility giving new dimensions to femininity, to its mystery and enigma.

Of course the biographic woman is the businesslike woman (in the broad sense of the word). The little black dress expresses businesslikeness as such — the right to businesslikeness, if you will. These stories are not merely an intrusion of the woman into the man's world in the form of new roles, social positions, and emancipatory conquests (although one often tends to reduce them to these). It is not the case that the woman starts to do things she has never done before (even though this, too, is part of the story); the woman starts to be present and to be who she is in those things, despite the danger of instrumentalising herself through them and the danger of blending into the image: from the nun to the prostitute. But in the little black dress this instrumentalisation is overcome by the power of the colour black which cancels all definitiveness. Thus, the businesslike does not possess only a heavy, dense reality and a clearly delineated action in the world's fabric. Despite its air of frivolity, the little black dress is a phenomenon of maturity, of ripe femininity; the dress expresses a kind of maturity which is immanently temporal in that it is past, action and perspective all in one. The little black dress represents a femininity which is both realised and realising; that is why when young girls want to look grown up they often reach for the little black dress as if trying to make up for all the days they have not yet lived.

The businesslike is also declared as the right to invent and to be invented, i.e. it is in the ephemeral space of dreaming. Once again, this is not merely a flight of fancy: it rests on the objective ontological status of the rumour. This is why the woman in the little black dress is always a promise beyond what she is, an invisible presence, independent of the limits of her actualisations. As a result, she is always forthcoming, which makes her a phenomenon of expectation and different from the man's black suit which is comparatively dull in its everyday businesslike nature. Now the woman no longer hides in the garment's folds and volume. Therefore, if the luxurious garments of the past symbolise the simplicity and static nature of life then the simplicity of the little black dress represents the multiplicity of stories, stories both already happened and stories to come - the possibility to be invented. 
The preceding can be formulated more precisely if we return to the unique interplay among the body, the colour black, and the smallness that we observed in the little black dress. Earlier we noted that black clothing and the female body have a long history together, but here we will not expand on this theme. It is evident that the main dynamic now is being posited by the "work" of "the small" on the body and on the colour black. Even a cursory glance into history will show that, almost without exception, the female dress was long, fully covering a woman's legs. Thus, the lower part of her body remains invisible in itself and is being shown only through the dress. Whatever the variations of the long dress, they always give a rounded bell shape to the woman's body from the waist - even from the chest - down. It is not difficult to find in this roundness a representation of the womb. As such, the long dress represents the woman via the mystery of conception and birth, as the comforting force of motherhood. By virtue of the garment and its length, the woman becomes a well guarded womb. In this case, the act of undressing is an act of using the body as a nature which conceives and gives birth. The long dress situates the woman in this blessed locus of original life and of the immediate possibility and comfort of being while keeping in its circle an eternal dimension of femininity.

This is why the shortening of the dress and the uncovering of the legs (up to the knees) is an act of fundamental importance. Up until that moment in the history of female clothing a woman revealed her naked body predominantly in the expressiveness of her head and the marvellous landscape of her shoulders and breasts. The body's impulse for freedom is bursting through the shelter of the long frock which is evident in the design of some of the dresses in the $18^{\text {th }}$ century: they reflect the gesture of rashly stripping the body of its clothing wherein the body parades its newfound freedom which is like a deliverance from the womb, like a shedding of the skin. However, this evolution is still not complete. In fact, the dress dominates in such a way that the revealed shoulders and breasts - a woman's "showcases of jewellery" - actually emphasise and make more defined the natural feminine vitality hidden in the long dress, giving it a strong erotic and sexual tone which paves the way, so to speak, to that "obscure object of desire". The uncovering of the legs is, of course, one more step in that direction - this time from the bottom up. But this event - and I insist on using the word "event" - is much more than that. In the beginning of this paper I related it to the freedom of the body and the possibility of movement, but we should go beyond their physical meaning. The freedom of 
movement is only one dimension - and not even the most important one - of a grander, more holistic act. The uncovering of the legs is an ontological violation, because it shortens and minimises what was until then the very foundation of femininity - the womb. Shortening the dress and revealing the legs gives them a scissor-like quality; this act is like a surgical intervention with a double effect: on the one hand, it reduces the space of this womb dimension of femininity, while, on the other, it uncovers the otherness hidden in the woman, emancipating her from sinking within herself (it is no coincidence that the scissors were Coco Chanel's favourite tool with which she never parted). In other words, we are witness to the genesis of a new femininity and we can easily say that it is being born from the legs, that it escapes from there much like Athena did from Zeus' head, with all of the consequences stemming from this. In this way, the legs appear to become a principal emancipatory organ because their appearance delineates a border within the body and is a clear sign for the beginning of a movement of the woman beyond her confines, a sign that she is coming out of herself like nature when giving birth, a sign for a nascence that goes beyond motherhood; and, most of all, a sign for the possibility of a narrative beyond all of this. In this way, the secret guarded by the long dress is no longer only natural, but also biographical; here, conception and birth, or motherhood, is a stage that is not equal to the whole. The emancipatory meaning of the little black dress lies in the fact that it separates the woman from her kin and individuates her history. This is no longer a "woman's story" in which different women blend into one another, but rather the story of "this woman".

We must be careful not to let ourselves be entirely swept away by the legs, as often happens. For, regarded on their own, they would lead us to a woman who is not the woman in the little black dress. They would lead the man to a woman in a short skirt in whom the motherly principle is on the verge of being extinguished. It is not perchance that the short skirt has, in more recent times, become something of a uniform for the prostitute who displays women as just legs - a barren sexuality, a pure objectness constituting the body as a sexual mechanism.

But the legs can also lead the woman to an unbalanced, hysterical femininity which regards the body only through the mobility of the legs and finds as its ultimate purpose the escape from an everlasting form of femininity.

That is why the woman in the little black dress is not a woman running away from motherhood - even though motherhood is minimised, it retains a perceptible and resolute presence. She is now the woman who can do it. But if she loses herself 
in doing it, she will no longer be the woman in the little black dress. The mere act of escaping by virtue of the freedom of her legs is always some kind of amputation.

That is why we have to maintain this astonishing balance among body, blackness, and smallness which the little black dress carries within itself. For, if we now place the emphasis on the colour black, if its own power becomes the leading force expressing itself in the exquisite fineness of the cut, then the woman in the little black dress could turn into something demonic; she could become a manifestation of the vampiric, the devil incarnate in a woman's image. Then the mood becomes apocalyptic and the erotic starts to carry with itself the images and reincarnations of death.

We have to contain the image of the woman in the little black dress within a space where she is both real and fictitious, where she appears in the indeterminacy of rumour; for the little black dress minimises yet does not deny anything - on the contrary, it affirms everything. The little black dress gathers together the pieces of femininity scattered over time and preserves the woman in the completeness of her historical presence. And it does this not merely within the dimension of historical facticity, but also in that ephemeral reality which illuminates things and is open to the imagination.

The woman in the little black dress is the rumour about which Homer says that, through it, the gods communicate their message to us.

\section{REFERENCES}

Asenov, S. (2014). Bitie i otsastvie. Dostoevski i opitat sas smartta [Being and Absence. Dostoevsky and the Experience of Death]. Sofia: Sofia University Press. (in Bulgarian).

Eco, U. (Ed.). (2006). Istoria na krasotata [History of Beauty]. Sofia: Kibea Pubishing House. (in Bulgarian).

Gidel, H. (2008). Koko Shanel: biografiya [Coco Chanel: Byography]. Sofia: Riva. (in Bulgarian). Lipovetskii, Zh. (2012). Imperiya efemernogo. Moda i ee sud'ba v sovremennom obshchestve [The Ephemeral Empire. Fashion and its Destity in Modern Sosciety]. Moscow: New Literary Observer. (in Russian). 